\title{
Importance and Limitations \\ of the Leicester Group Theory towards the Comprehension of Delinquent Behaviour of Ultra Groups of Oporto
}

\author{
Daniel Alves Seabra
}

${ }^{1}$ Graduate School of Physical Education, National Institute of Fitness \& Sports in Kanoya, Japan

KEYWORDS

With this paper and the communication that will be presented, I will produce the results of an investigation about four Ultra groups that support the top three football clubs of Oporto, known in Portugal as claques. I intend to state the main reasons that allow me to consider the Leicester Group theory the best in order to understand the hooliganism and delinquent behaviour of some members of Ultra groups in Oporto. The main points of the theory will be compared with the corresponding empirical data that confirms it. There are 47 neighbourhoods in Oporto, which makes it the Portuguese city with the greatest number of these neighbourhoods. More than 20,000 people $20 \%$ of the population of Oporto - live in this type of well-identified territory in urban space. Quantitative and qualitative data, obtained through participant observation, interviews, life stories and inquiry by questionnaire, reveal the presence of a social configuration that the Leicester Group proposes in order to explain football hooliganism. This data also allows me to confirm that delinquent behaviour and some violence that could be observed in a football context can be seen as a social reproduction of a delinquent course already present in everyday life. The limitations of the Leicester Group theory will also be considered. This investigation has found that these supporters have a strong sense of belonging to their community and to their city, which is also symbolically reproduced in football stadiums. Finally, I will propose the concept of social experience as an adequate concept to study this kind of social phenomenon.

football hooliganism; ultra groups; delinquent behaviour; Leicester Group

Oporto is the second city of Portugal. The most important club of the city is obviously Futebol Clube do Porto, but Boavista Futebol Clube and Sport Comércio e Salgueiros are also two clubs with an important role in the Sport and Social History of Oporto. All these clubs are supported by Ultra groups, which in Portugal are known by the French word claque and can be defined as a group, with a specific name, whose members regularly occupy the same place in stadiums in order to actively support their team through songs, applauses, flags, scarves, banners, and smokes (Pereira 2002). Ultra groups differ from the general supporters that are watching the match not only by the visibility of their 
choreographies and symbolic manifestations, but also by the Ultra attitude of their members. To become an Ultra, the members of the group must be present at all games and in all conditions; even in bad weather and even when the price of a ticket is too expensive. An Ultra could suffer threats and attacks from an opponent's supporters; in these cases, the other members of the group are obliged to demonstrate solidarity and defend him/her. This kind of extreme militancy is the basic principle and philosophy of Ultra Movements and should be the model for all Ultra groups. The main values of this movement are loyalty to the 'club's colours', solidarity and cohesion (Lago 2001). According to these basic principles and philosophy, violence and delinquent behaviour are unacceptable and reprehensible and should be understood as a perverse effect of this kind of active support. Violence can only be admitted in some cases of personal defense against attacks.

The Ultra Movement is also the model that the Ultra groups of Oporto want to follow. Futebol Clube do Porto is supported by two Ultra groups, Super Dragões and Colectivo Ultras 95; Boavista Futebol Clube receives the support of Panteras Negras; and Alma Salgueirista supports Sport Comércio e Salgueiros.

Despite identification with the founding values of the Ultra Movement, some members of Super Dragões, Colectivo Ultras 95 and Panteras Negras are responsible for acts of violence that could be considered as football hooliganism - the most important and serious of which is the organised and planned fighting against members that support rival teams, or simply aggression that injures supporters of other teams. They also commit acts of delinquent behaviour, an example of which is stealing various objects in several stores when these groups travel to the opposing team's stadium.

It is essential to stress that this kind of behaviour is least frequent among the Ultra groups of Oporto. However, the violent and delinquent behaviour of a few members receives much attention by the media, and even small facts are a good reason for sensational news coverage. On the contrary, it is difficult to find news about the sound, colours, choreographies, and show that Ultra groups present in Portuguese stadiums. Consequently, it is not a surprise that public opinion about Ultra groups is very negative. Violence and delinquent behaviour also have political implications. The Portuguese government passed legislation in order to prevent and avoid incidents and to punish the guilty. Thus, the aim of this paper is, precisely, to demonstrate that the Leicester Group theory is the best for comprehending this kind of behaviour in the Ultra groups of Oporto.

\section{The Leicester Group theory}

(Dunning, Murphy \& Williams 1992a, pp. 368-388)

(Dunning, Murphy \& Williams 1992b, pp. 184-245)

This theory tries to explain Hooliganism as a consequence of a specific social configuration which comprises, in summary, the following intercorrelated features:

1. Many hooligans belong to the lower working class. They have mostly unskilled and semiskilled jobs. Their educational capital is also low. They have a high rate of school failure;

2. Many hooligans live in working class neighbourhoods, where sociologists who constitute the Leicester Group found a sort of community with features that Suttles also found in his investigation concerning communities in Chicago characterised by 'Ordered segmentation' (Suttles 1968). The following points will present the main features of the life pattern found in these kind of communities;

3. Little parental control in everyday life. As a result, socialisation occurs among peer groups in the street, where a tendency for aggressive behaviour between them was observed. Emergence of 'street corner gangs'. Some hooligans only earn money through informal 'street economies';

4. A great number of family conflicts with a high level of male violence against women that is not punished. Physical punishment is also an educational practice. Violence and delinquent behaviour become a model of authority that young people embody; 
5. A large number of conflicts between neighbours;

6. A strong sense of belonging to the community, which is very important when conflicts arise with other neighbourhoods. In that case, all family and neighbour conflicts lose their relevance in view of a new conflict against another rival community. Nevertheless, these rival groups of the same city could become allied if the conflict is against groups of other cities.

7. This 'ordered segmentation' is reproduced in football stadiums by the fighting between groups. Finally, the football stadium is understood as the place where the masculine aggressiveness, violence and territorial identification that this kind of social configuration promotes are reproduced and exacerbated.

\section{Empirical data about the Ultra groups of Oporto}

With the following data I will consider the same points exposed by the Leicester Group theory and the necessary correspondence between them and the empirical data. These were obtained through participant observation, interviews, life stories and inquiry by questionnaire $(1,750$ as the estimated population size - cluster sampling composed of 200 inquiries by questionnaire).

\section{About social class, employments and educational level}

Membership in the Ultra groups of Oporto is comprised of $85 \%$ men and $15 \%$ women. Considering each group: Super Dragões has $85 \%$ men, Colectivo Ultras $9582 \%$ men, Panteras Negras 77\% men, and Alma Salgueirista 91\% men. But the most significant fact is that only one woman presents the fight against rival supporters as a motivation to integrate an Ultra Group. No women present theft as a reason to integrate the group. Planned fights and thefts are almost exclusively perpetrated by the male members. The Ultra groups of Oporto are composed of $75 \%$ of members whose age is between 15 and 29 years old. It is clear that all groups are young - the average age is 26 years old. Super Dragões and Colectivo Ultras 95 have an average age of 25 years old, while the average age of Panteras Negras is 28 years old and Alma Salgueirista is 29 years old. In terms of social class, data reveals that $23 \%$ work as non-manual workers of lower rank, $18 \%$ are students and $13 \%$ have unskilled and semi-skilled jobs. Super Dragões is $33 \%$ students, $21 \%$ of whom are nonmanual workers of lower rank, and 11\% have unskilled and semi-skilled jobs. Colectivo Ultras 95 has $20 \%$ non-manual workers of lower rank, $24 \%$ students, and $10 \%$ with unskilled and semi-skilled jobs. Panteras Negras has $30 \%$ non-manual workers of lower rank, $10 \%$ students and $15 \%$ with unskilled and semi-skilled jobs. Alma Salgueirista has 31\% non-manual workers of lower rank, 31\% with unskilled and semi-skilled jobs, and $12 \%$ students. All groups have some members that belong to the middle class and upper class, especially Colectivo Ultras 95. However, the predominance of members who belong to the working class is clear. This belonging is reinforced by the professions of their parents, who can also be enclosed in the working class. Concerning the educational capital, $77 \%$ of all members of Ultra groups have failed at least one year of their educational trajectory. In all groups, the highest percentage of members (70\% in Super Dragões, $75 \%$ in Colectivo Ultras $95,60 \%$ in Panteras Negras and $93 \%$ in Alma Salgueirista) have failed the 12th grade or lower. Considering the age of most members, school failure is clear, despite a significant percentage $(27 \%)$ that have a high education level.

\section{About hooligans who live in working-class neighbourhoods}

There are 47 neighbourhoods in Oporto, which makes it the Portuguese city with the greatest number of these neighbourhoods. More than 20,000 people $-20 \%$ of the population of Oporto - live in this type of well-identified territory in urban space. Concerning violence and theft, there are several group members who claim that such acts are mostly carried out by elements from neighborhoods.

'You cannot say it's only people from neighbourhoods. But of course it's more them.' 
'It's more them. Not to say it's only them.'

This is recognised by some members who live in these kind of neighbourhoods.

'I used to go with Super Dragões. I went to the matches with them, but only to rob the others.'

Some members explained the reasons for this kind of behaviour:

'Of course guys coming from Oporto's neighbourhoods and that along with the claque's activity showed signs of delinquency. If they steal from Monday to Saturday, they're also going to do it on Sundays. They're used to stealing.'

A Super Dragões member that lives in a neighbourhood and already has a criminal career said:

'In neighbourhoods you can find drugs, thefts, car robberies and everything. The guys don't have a degree but they have life. They've already stolen many times, not only in the matches but also with their fellows from the neighbourhood." "We're talking about guys with money difficulties. People who are used to stealing in their daily life. Then they get there and do the same.'

\section{About little parental control, socialisation among peer groups in the street and the tendency for aggressiveness and delinquent behaviour}

'My father passed away and my mother had to work to cope with everything.'

'My father left my mother because he was addicted to gambling. My mother had to get two jobs to support our home. I never had a deep contact with him.'

'My father has always been away. We live with lots of difficulties.'

'I lived with my mother, who was both a mother and a father. I have no appreciation for my father. I don't even speak to him.'

'I had six brothers and sisters and my father left us. I left school and had to support my family. I had to go into stealing.'

'I used to go out in the morning and came back at night. Not that my mother didn't worry. But she didn't control me. We used to go in a big group of kids.'

'We used to get together in a group and that was it. We screwed up. Stealing.'

'Unfortunately some parents are drug addicts and children become mean and angry. Teachers are insulted. Pupils already stand up to teachers.'

'I grew up in that because when we went to school we had a snack only because when we went by the grocery running we'd eat what we could catch. Some could eat because they used to take the snack of the schoolbags.'

'I saw them on a trip stealing toys and then they looked at them as if they were children. Many never had a toy in their whole life.'

\section{About family conflicts, male violence and physical punishment as an educational strategy}

'I don't live with my father. He's married to another woman but he was with my mother for twenty years. He gets into drugs and then becomes crazy. I know my father used to beat my mother.'

'There was a lot of violence. The man's power was much more put to use than nowadays. There were a lot of family conflicts in there. We saw such scenes... Once there was a husband that got home and then a pan with hot water came out of the window. But those are family matters and no one intrudes. That's what you can see all over in neighbourhoods.' 
'I was mad at my mother many times. I have scars of when she attacked me with a knife here. We even got into beating each other up and I tried to kill myself with pills.'

'It's the way they live, you see? The father himself was a dealer. So were the grandparents. And they grew up in that.'

'In the neighbourhood there are mothers that insult their own children.'

\section{About conflicts between neighbours}

'There was beating up every day. All over. They were all drunk.'

'There was a lot of violence in the neighbourhood. There were even gunshots.'

'There were quarrels in families, among neighbours. Problems with the police and everything.'

'There are conflicts with stones and shots inside the neighbourhood.'

\section{About the strong sense of belonging to the community, which is very important when conflicts arise with other neighbourhoods}

Despite all conflicts, people who live in neighbourhoods also have great cohesion among them and great identification with the territory where they live, a fact underlined by several neighbourhood inhabitants.

'If there is a row of course people become violent. But neighbourhood people get on very well with each other.'

'People are very close in neighbourhoods. They know each other very well and if they're in trouble they know they can call a neighbour. We were all born there and whoever beats one beats all of us. We're really close.'

'People could even not get along, but if there's a mess with someone from outside, the ones that are angry at you are the first to help you.'

'In Oporto there has always been rivalry between neighbourhoods.'

'There are neighbourhood members that are constantly robbed by members of other neighbourhoods.'

'There are brawls during the week between neighbourhoods and then they meet at football and the day of reckoning comes.'

\section{About the reproduction of the 'ordered segmentation' in football stadiums}

The participant-observation that was carried out among the four Ultra Groups of Oporto enabled the observation of fighting between Panteras Negras e Alma Salgueirista and between Colectivo Ultras 95 and Panteras Negras. However, the same Ultra groups that fought on a certain weekend can be united at the end of the week after a fight against a rival Ultra group of Sport Lisboa e Benfica or Sporting Clube de Portugal, both from Lisbon, the capital. The Ultra groups of Oporto are very proud to be from this city. In its history we can also find the same critical discourse against Lisbon, which is considered to have always received almost all financial and political benefits. In conclusion, we can regard this data and the relationships between them as a social configuration that promotes and reproduces violence and delinquent behaviour, not only in everyday life but also in the form of hooliganism found in the context of football .

\section{The limitations of the Leicester Group theory towards the comprehension of hooliganism} and the delinquent behaviour of the Ultra groups of Oporto

Considering the results of the investigation and the more relevant data presented here, it is clear that the Leicester Group theory is the best tool - though not the only one - for comprehending the 
violence and delinquent behaviour of some members of the Ultra groups of Oporto. In spite of this, the following limitations are also clear:

- The Leicester Group recognises that the members of the groups who come from working-class neighbourhoods are not the only hooligans. Some of them have good behaviour inside the group, with no participation in violent or delinquent acts. That is the case of Alma Salgueirista. This is the group that has the greatest number of members who belong to the working class; some of them also live in a working-class neighbourhood. However, no act of violence or delinquency was observed during the field work. Even in the other groups, there are many members who belong to the working class and live in the same neighbourhoods but have never been involved in violence or delinquency. They also have a highly critical discourse against all other members who engage in such acts;

- On the contrary, some members that belong to the middle class and even the upper class also participate in acts of hooliganism and robbery. It is true that this participation does not exhibit the same show off and aggressiveness. However, those acts are much better planned and rationalised. Some members of Colectivo Ultras 95 illustrate this example well;

- It must emphasised that hooliganism and delinquent behaviour are only one dimension - the least frequent but the most visible and publicised - of the Ultra groups of Oporto. Other dimensions that contribute to understanding this kind of group in their globalism and complexity should be taken into account: participation in the group as exciting leisure; as a ritual to support the team with which all have a great identification; as an alternative society and youth subculture where the members seek a sense of honor; personal and collective identity. All of these factors can give a complete frame in order to understand and interpret this social phenomenon. The Leicester Group theory is only focused on hooliganism, while Ultra groups are much more than hooliganism;

\section{Social experience as a concept that could help the comprehension of Ultra groups}

The importance of this concept was already recognised by Canter, Comber \& Uzzell (1989). Even Norbert Elias, also associated with the Leicester group, in affiliating the theoretical perspective which regards the social group as most responsible for hooliganism, as well as commenting on its provenience, stated that "it is the human experience, characteristic of this social group, that has to be felt and evoked, if we intend to find the explanation to the eruption of violence" (Elias, 1992, p. 91).

Deeply rooted in the phenomenological philosophy, this concept, defined by Dubet as the dynamic and reflexive relationship that people have with their social environment, allows us to consider and conjugate the structural dimension and the subjective dimension of the social agent. The first encompasses not only the participation in a group and adherence to its values and rules, but also the social structures in which members are inserted, including social class, age structure, gender, family, religion, politics and social spaces. It is also possible to understand, using the members' own words, this logic of integration in the structural dimension. The second dimension covers the strategic logic and subjective logic always present when a member of the group goes to the Ultra groups. They are able to expose their motivation for belonging to the group - supporting the team is the most reported but some members find in the group the opportunity to earn money and therefore the chance for social mobility - and the personal meaning that they give to the participation. With this concept the potential exists to establish a good balance between the structural frame, where the member is coming from and also where he or she will have to enter when deciding to become an Ultra, and his or her position as a social agent that gives options and a meaning to his or her condition of an Ultra group member.

In this investigation about the Ultra groups of Oporto, it becomes obvious that other theories should be considered and it is necessary to assess the relevance of each of them, case by case. No theory, by itself, reveals the extent necessary to understand the groups in their diversity and 
complexity. Besides allowing us to combine the structural and subjective dimensions, the social experience concept can be the basis for establishing the necessary comparative and interpretative framework, which should begin from a deep empirical work, as Spaaij advocates.

\section{REFERENCES}

Canter, D., Comber, M. \& Uzzell, D. L. (1989). Football in its place. An environmental psychology of football grounds. London \& New York: Routledge.

Dunning, E., Murphy, P. \& Williams, J. (1992a). A violência dos espectadores nos desafios de futebol: para uma explicação sociológica. In N. Elias (Ed.) A busca da excitação (pp. 368-388). Lisboa: Difusão Editorial Lda.

Dunning, E., Murphy, P. \& Williams, J. (1992b). The roots of Football Hooliganism. An Historical and Sociological Study (4 ${ }^{\text {th }}$ ed.) London \& New York: Routledge.

Elias, N. (1992). Introdução. In N. Elias (Ed.) A busca da excitação (pp. 39-99). Lisboa: Difusão Editorial Lda. Spaaij, R. (2006). Understanding Football Hooliganism. A comparison of Six Western European Football Clubs. Vossiupers: University van Amsterdam.

Suttles, G. D. (1968). The social order of the slum. Chicago: The University of Chicago Press.

AUTHOR'S ADDRESS: $\quad$ Daniel Alves Seabra

Fernando Pessoa University

Praca 9 de Abril n. 349

4249-004 Porto, Portugal

Email: das@ufp.edu.pt 